\title{
Patient Autonomy and Informed Consent in Critically III
}

\author{
Zoran M. Todorovićc ${ }^{1,2}$, Dragana D. Protić ${ }^{1}$ \\ ${ }^{1}$ Department of Pharmacology, Clinical Pharacology and Toxicology, School of Medicine, \\ University of Belgrade, Belgrade, Serbia \\ ${ }^{2}$ University Medical Center "Bežanijska kosa", Belgrade, Serbia
}

\section{SUMMARY}

Introduction: Patient autonomy has been a cornerstone of contemporary clinical ethics since the Nuremberg trial, especially in American school of bioethics.

Topic: Patient autonomy has been defined in the Nuremberg Code, and re-defined in the Declaration of Helsinki, Belmont Report and Barcelona Declaration. Founders and followers of the rights-oriented bioethics (for example, Hellegers, Beauchamp and Childers) have established and promoted the patient autonomy as the main principle of bio(medical) ethics since 1970s. However, there is a lot of controversy surrounding such a principle, especially in vulnerable patients. We aimed at evaluating the real meaning and value of patient autonomy in critical care settings regarding the communication between health workers and their patients and families.

Conclusion: Protection of patients autonomy in critically ill is a complex issue. Careful benefit-risk assessment is needed in order to find the most appropriate way of obtaining the informed consent, proxy consent or to omit or delay it.

Keywords: patient autonomy, drug development, pharmacotherapy

\section{INTRODUCTION}

Patient autonomy is the main principle of contemporary rights-oriented bioethics [1-6]. Andre Hellegers, a physician and professor of obstetrics, physiology and biophysics developed a concept of biomedical ethics focused strictly on medical issues, ie. human medicine. Autonomy is inherent to the American culture and liberal individualism. The patient's right to decide is rooted in American tradition of personal liberties and privacy rights [7]. Of note, there is completely different, responsibilityoriented approach to bioethics, established and developed by Fritz Jahr and Van Rensse- laer Potter. In contrast to the previous concept, Potter's vision is holistic. It involves all living creatures in the interaction with the environment. Basic principles of the responsibilityoriented bioethics are beneficence/nonmaleficence and justice. Ultimately, rights-oriented approach fits better into the individual ethics, while responsibility-oriented approach is closer to the collective ethics [8].

Autonomy involves two important steps: (1) patient with decision-making capacity makes autonomous decision about his health and treatment, and (2) health workers give the advice and conduct the treatment according to the patient's choice. It seems rea- 
sonable to consider that patient autonomy has instrumental value in promoting wellbeing [9]. However, certain philosophers argue that health care providers are sometimes in good position to decide what is better for their patients, and informed consent is neither necessary nor sufficient for ethical clinical research in some cases [10-12]. Additionally, there are patients without decision-making capacity (for example, vulnerable subjects and groups), and autonomy is restricted in certain cases (for example, weakness of will, external influences - coercion/manipulation, and lack of information). In cases where individual participant is not capable of providing valid informed consent, a substitute decision-maker (SDM) is allowed to legally confirm the acceptance for participation in the study. SDMs do not often accurately represent participants' wishes [1315]

A notorious example of disrespect for patients' autonomy is the Tuskegee study (syphilis experiment). There are, however, more subtle cases of such a disrespect in medical practice. One could argue that patient autonomy is not restricted just to the promotion of wellbeing (instrumental value) but has an intrinsic value as well. In medical practice, there is also false autonomy, that could be best described as 'Brave New World' model of manipulation with patients attitudes in order to make them happy in an artificial way.

The aim of our study is to evaluate the real meaning and value of patient autonomy in critical care settings regarding the communication between health workers and their patients and families. Pros and cons of the current model of autonomy in critically ill will be discussed according to the findings from the literature, and authors' personal opinion. Google was searched for publications on the patients' autonomy in critical care settings. The following keywords were used: "informed consent" AND "critical care". Retrieved citations were limited to those published between 2007 and 2017 in English.
Table 1. Basic bioethical principles: American vs. European school of bioetics

Belmont Report
(American school of bioethics)
Respect for Persons
- respect for autonomy and
- protection of people with diminished autonomy
(immature and incapacitated)

Auton

Autonomy

- the capacity of creation of ideas and goals for life

- the capacity of moral insight, etc.

- the capacity of rational decision and action without coercion

- the capacity of political involvement and personal responsibility

- the capacity of informed consent

\section{Beneficence}

- respect for individual's decisions, in order to

- protect them from harm, and

- to secure their well-being

Justice

- fairness in distribution of benefits and burdens of research

- equal distribution to each person

- an equal share

- according to individual needs

- according to individual effort

- according to societal distribution

- according to merit
Dignity

- intrinsic value of the individual

- inter-subjective value of every human being in its encounter with the other

\section{Integrity}

- inviolability of the human being

- quality of the person as such

- coherence of life in time and space (in memory and corporeal life) that should not be touched and destroyed

- respect for integrity = respect for privacy and personal environment, in particular for patient's understanding of his/her own life and illness in body and soul

Vulnerability

- concerns integrity

- all life could be hurt, wounded and killed

- respect for vulnerability = recognition of the finitude of life 
TOPIC

\section{Informed consent in vulnerable subjects}

Vulnerable persons are relatively (or absolutely) incapable of protecting their own interests. They could be particularly susceptible to undue influence (coercion, manipulation, persuasion) [16-22]. Protection of their autonomy is not just restricted to the informed consent (given usually by their legally-authorized representative), but it is an ongoing process. Table 1 shows basic bioethical principles.

Full protection of the autonomy of vulnerable subjects obviously depends on the interplay between all presented bioethical principles. Such an issue is even more complex if we discuss the autonomy of critically ill.

Informed consent is a voluntary agreement of individual or his/her legally authorized representative to participate in the study. It is "a process by which a subject voluntarily confirms his or her willingness to participate in a particular trial, after having been informed of all aspects of the trial that are relevant to the subject's decision to participate. Informed consent is documented by means of a written, signed and dated informed consent form." (ICH GSP Glossary). Informed consent should fulfill the following mandatory conditions stated in the Belmont report: adequate information about the study (risks and benefits explained), the patients' comprehension, and the voluntariness [23].

According to the CIOMS International Ethics Guidelines for Health-related Research Involving Humans, "adults who are not capable of giving informed consent must be included in health-related research unless a good scientific reason justifies their exclusion." Valid informed consent from the legally authorized representative and the assent from the subject must be obtained. If there is no obvious benefit for such participants, the intervention should be conducted first in persons who are capable of giving informed consent, and the risks of the intervention must be minimized, and no more than minimal [6].

The assent of the incapacitated subject should be respected even if the legally authorized representative signed the consent. However, the assent could be also overruled (a) if the study offered the only available treatment, (b) which has been previously confirmed to be beneficial for the vulnerable subject, and (c) the agreement to conduct the study was reached both by treating physician and legally authorized representative.

\section{Informed consent in critically ill patients}

Critically ill patients belong to vulnerable subjects [24]. Accordingly, the achievement of a valid informed consent is a challenging issue. Clinical trials in such a cohort could be ethically acceptable if additional protecting mechanisms are in place to minimize risks. Such a research is needed in order to develop new drugs for their own good. Also, clinical trials in critically ill fulfill the social value requirement [25]. However, there are no specific guidelines on the research involving critically ill patients [26-29].

Making decisions is a hard work even in the mature, autonomous person [30]. It is even worse and more complex issue in critically ill and their relatives. Majority of literature on the autonomy of critically ill deals with extreme situations (for example, end-of-life cases), but routine medical care is usually more important for the assessment of real meaning and value of the informed consent and patientphysician interaction. Assent is even more common in such a routine care than the appropriate autonomy-based consent. Critically ill patients rather agree with the procedure than make their own choice.

Decision-making capacities of patients with acute illnesses could be dimished [31]. There are two types of errors in obtaining informed consent from critically ill. First, surrogate consent is obtained from the legallyauthorized representative despite the patient's capability to provide valid consent. Second, informed consent is required from critically ill who lacks the decisional capacity. Another problem is "therapeutic misconception" ie. participants misconstrue that clinical trial (research) is therapeutic process [32]. In other words, critically ill may misunderstand that a research procedure (for example, randomization) is tailored to their personal needs, or they may hold unreasonable appraisal of the likelyhood of personal medical benefit from the study participation.

Careful reading of the informed consent form is of a vital importance for understanding the benefits and risks properly. Simplified forms of informed consent might improve understanding [33]. Informed consent training of physicians might be of a great value as well [34]. 
Capacity assessments methods are not standardized. Some of them are timeconsuming and not appropriate for use as a screening measure. However, University of California, San Diego, developed a shorter form, Brief Assessment of Capacity to Consent (UBACC) [35]. There are less formal methods for the capacity assessment.

Proxy consent requres legal guardian (legally-authorized representative). Such a representative might be appointed in advance, or "naturally chosen" (for example, family member or friend). Proxies are supposed to know patients preferences in making a decision, but is does not seem to be realistic. Instead, they should consider what would be in the best interest of the patient.

Silverman [24] proposed different safeguard levels depending on the risk of the procedure with critically ill. For example, when the risk is minimal, safeguards involve a written plan on the methods to assess decision making capacity, and methods to obtain proxy consent, assent and dissent, and re-consent if possible.

Chenaud et al. have shown that patients in the intensive care units suffer from poor recall of participation in a clinical trial, as well as purpose and the risks, which may preclude obtaining of valid informed consent [36].

Waiver of informed consent is allowed when the research has an important social value, poses no more than minimal risk to participants, and would not be feasible without the waiver. That is the the case in emergency research (for example, unconscious patients with septic shock) [37].

Finaly, we may agree that true autonomy of the critically ill should be strengthened and enhanced. Residence education should be adjusted and clinical ethics should be incorporated into ward rounds. All other medical staff (for example, nurses, technicians and social workers) should be instructed and trained to improve their communication skills. Institutional paternalism, even in its subtlle form, should not replace the true communication between critically ill and their physicians regarding major health-related decisions.

\section{CONCLUSION}

Protection of patients autonomy in critically ill is a complex issue. Careful benefit-risk assess- ment is needed in order to find the most appropriate way of obtaining the informed consent, proxy consent or to omit or delay it. A set of safeguards could be applied depending on the risk of the procedure and the expected befit of the trial. Ultimately, there is a shift from rights- to responsibility-oriented bioethics regarding the respect to autonomy in critically ill, as well as the shift from American to the European principles of bioethics defined in the Barcelona Declaration with vulnerability as a cornersone.

\section{ACKNOWLEDGMENT}

This work was supported by the Grant from the Ministry of Science of Montenegro, No. 01-1370 and 01-907/2.

\section{REFERENCES}

1. Dupras C, Ravitsky V, Williams-Jones B. Epigenetics and the environment in bioethics. Bioethics. 2014;28(7):327-34.

2. "Trials of War Criminals before the Nuremberg Military Tribunals under Control Council Law No. 10", Vol. 2. Washington, D.C.: U.S. Government Printing Office, 1949: 181-2. Available at: https:// history.nih.gov/research/downloads/nuremberg. pdf.

3. World Medical Association. World Medical Association Declaration of Helsinki: Ethical Principles for Medical Research Involving Human Subjects. JAMA. 2013;310(20):2191-4.

4. Kemp P, Rendtorff JD. The Barcelona Declaration: Towards an Integrated Approach to Basic Ethical Principles. Synthesis Philosophica. 2008;23(2):23944.

5. United States. The Belmont Report: Ethical Principles and Guidelines for the Protection of Human Subjects of Research. Bethesda, Md.: The Commission, 1978.

6. International Ethical Guidelines for Health-related Research Involving Humans (4th ed). Geneva: Council for International Organizations of Medical Sciences (CIOMS), 2016.

7. Wolpe PR. The Triumph of Autonomy in American Bioethics: a Sociological View. In: DeVries R, Subedi J (eds). Bioethics and Society: Sociological Investigations of the Enterprise of Bioethics. Upper Saddle River NJ: Prentice Hall, 1998: 38-59.

8. Heilig CM, Weijer C. A critical history of individual and collective ethics in the lineage of Lellouch and Schwartz. Clin Trials. 2005;2:244-53.

9. Varelius J. The value of autonomy in medical ethics. Med Health Care Philos. 2006;9(3):377-88. 
10. Buchanan AE, Brock DW. Deciding for Others: The Ethics of Surrogate Decision Making. New York: Cambridge University Press, 1990.

11. Beauchamp TL, Childress JF. Principles of Biomedical Ethics (5th ed.). New York: Oxford University Press, 2001.

12. Emanuel EJ, Wendler D, Grady C. What makes clinical research ethical? JAMA. 2000;283(20):270111.

13. Parker MJ, de Laat S, Schwartz L. Exploring the experiences of substitute decision-makers with an exception to consent in a paediatric resuscitation randomised controlled trial: study protocol for a qualitative research study. BMJ Open. 2016;6(9):e012931.

14. Shalowitz DI, Garrett-Mayer E, Wendler D. The accuracy of surrogate decision makers: a systematic review. Arch Intern Med. 2006;166:493-7.

15. Ciroldi M, Cariou A, Adrie C, Annane D, Castelain V, Cohen Y, et al. Ability of family members to predict patient's consent to critical care research. Intensive Care Med. 2007;33(5):807-13.

16. Schwenzer KJ. Protecting vulnerable subjects in clinical research: children, pregnant women, prisoners, and employees. Respir Care. 2008 Oct;53(10):1342-9.

17. Todorović Z, Prostran M. Integrativna bioetika i vulnerabilne grupe. Jahr. 2013;4(8):711-3.

18. Todorović Z, Živanović A, Protić D. Bioetička pitanja u vezi sigurnosti lijekova kod vulnerabilnih skupina. Jahr. 2013;4(8):779-90.

19. Prostran MŠ, Todorović ZM. Primjena ljekova kod odabranih vulnerabilnih skupina: stare osobe $u$ kliničkim ispitivanjima. Jahr. 2013;4(8):759-71.

20. Todorović Z, Prostran M, Turza K (eds). Bioethics and Pharmacology: Ethics in Preclinical and Clinical Drug Development. Kerala, India: Transworld Research Network, 2012: 1-160. (ISBN: 978-81-7895579-7)

21. Prostran MŠ, Todorović ZM, Stojanović RM, Potpara TS, Nešić ZI, Lazić JL, et al. Bioethics in clinical trials: vulnerable subjects. In: Todorović Z, Prostran M, Turza K (eds). Bioethics and Pharmacology: Ethics in Preclinical and Clinical Drug Development. Kerala, India: Transworld Research Network, 2012: 87-100. (ISBN: 978-81-7895-579-7)

22. Medić B, Todorović Z, Savić Vujović K, Stojanović R, Prostran M. Oboljeli od rijetkih bolesti kao vulnerabilni ispitanici u kliničkim studijama. Jahr. 2013;4(8):715-24.

23. National Commission for the Protection of Human Subjects of Biomedical and Behavioral Research: The Belmont Report: Ethical Principles and Guidelines for the Protection of Human Subjects in Research. Washington, DC: US Government Printing Office, 1979.
24. Silverman H. Protecting vulnerable research subjects in critical care trials: enhancing the informed consent process and recommendations for safeguards. Ann Intensive Care. 2011;1(1):8. doi: 10.1186/2110-5820-1-8.

25. Wertheimer $A$. The social value requirement reconsidered. Bioethics. 2015;29(5):301-8.

26. Bonnie RJ: Research with cognitively impaired subjects. Unfinished business in the regulation of human research. Arch Gen Psychiatry. 1997;54:11720.

27. Department of Health and Human Services: Federal Policy for the Protection of Human Subjects, 45 CFR 46 Subpart A. Federal Register 1991;56:28016.

28. Silverman HJ, Druml C, Lemaire F, Nelson R: The European Union Directive and the protection of incapacitated subjects in research: an ethical analysis. Intensive Care Med. 2004;30:1723-9.

29. Liddell K, Bion J, Chamberlain D, Druml C, Kompanje E, Lemaire F, et al. Medical research involving incapacitated adults: implications of the EU Clinical Trials Directive 2001/20/ED. Medical Law Rev. 2006;14:367-417.

30. Meyers C. Cruel choices: autonomy and critical care decision-making. Bioethics. 2004;18(2):10419.

31. Schaeffer MH, Krantz DS, Wichman A, Masur H, Reed E, Vinicky JK. The impact of disease severity on the informed consent process in clinical research. Am J Med. 1996;100:261-8.

32. Appelbaum PS, Roth LH, Lidz C. The therapeutic misconception: informed consent in psychiatric research. Int J Law Psychiatry. 1982;5(3-4):319-29.

33. Young DR, Hooker DT, Freeberg FE. Informed consent documents: increasing comprehension by reducing reading level. IRB. 1990;12(3):1-5.

34. Thompson BM, Sparks RA, Seavey J, Wallace $M D$, Irvan J, Raines AR, et al. Informed consent training improves surgery resident performance in simulated encounters with standardized patients. Am J Surg. 2015;210(3):578-84. doi: 10.1016/j. amjsurg.2014.12.044.

35. Jeste DV, Palmer BW, Appelbaum PS, Golshan $S$, Glorioso D, Dunn LB, et al. A new brief instrument for assessing decisional capacity for clinical research. Arch Gen Psychiatry. 2007;64(8):966-74.

36. Chenaud C, Merlani P, Luyasu S, Ricou B. Informed consent for research obtained during the intensive care unit stay. Crit Care. 2006;10(6):R170.

37. Chenaud C, Merlani P, Ricou B. Research in critically ill patients: standards of informed consent. Crit Care. 2007;11(1):110. 


\title{
Autonomija pacijenta i informisani pristanak u kritično obolelih
}

\author{
Zoran M. Todorović1,2, Dragana D. Protić ${ }^{1}$ \\ ${ }^{1}$ Institut za farmakologiju, kliničku farmakologiju i toksikologiju, Medicinsko fakultet, Univerzitet u \\ Beogradu, Beograd, Srbija \\ ${ }^{2}$ Kliničko-bolnički centar "Bežanijska kosa”, Beograde, Srbija
}

\section{KRATAK SADRŽAJ}

Uvod: Autonomija pacijenta je kamen-temeljac savremene kliničke etike još od Nirnberškog procesa, posebno u američkoj školi bioetike.

Tema: Autonomija pacijenta je definisana u Nirnberškom kodeksu i redefinisana u Helsinškoj deklaraciji, Izveštaju iz Belmonta i Deklaraciji iz Barcelone. Utemeljitelji i sledbenici bioetike zasnovane na poštovanju prava (npr., Hellegers, Beauchamp i Childers) uspostavili su i promovisali autnomiju pacijenta kao osnovni princip bio(medicinske) etike još od sedamdesetih godina dvadesetog veka. Međutim, ima dosta kontroverzi koje su povezane sa ovim principom, posebno kada se radi o vulnerabilnim ispitanicima. Autori procenjuju stvarno značenje i vrednost autonomije pacijenta u jedinicama intenzivne nege uzimajući u obzir komunikaciju između zdravstvenih radnika i pacijenata, odnosno njihovih porodica.

Zaključak: Zaštita autonomije kritično obolelih je kompleksno pitanje. Pažljiva dobit/rizik procena je neophodna kako bi se pronašao najadekvatniji način za dobijanje, odlaganje ili odbijanje potpisivanja Informativne saglasnosti, pacijenta ili pravnog zastupnika.

Ključne reči: autonomija pacijenta, razvoj lekova, farmakoterapija 